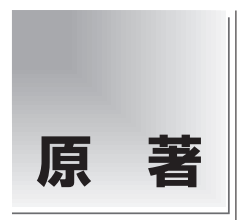

論文受付

2016 年 8 月 24 日

論文受理

2016 年 9 月 19 日

Code No. 333

\section{肝蔵腫瘍に対する呼吸同期 PET/CT の 非線形レジストレーション処理の有用性}

\section{我妻 慧 ${ }^{1} \quad$ 大澤達史 ${ }^{2} \quad$ 横川直樹 $^{2} \quad$ 三輪建太 ${ }^{3} \quad$ 織田圭一 ${ }^{1,4}$} 工藤善朗 ${ }^{2}$ 海野 泰 $^{2} \quad$ 伊藤公輝 $^{2,5}$ 石井賢二 ${ }^{1}$

\author{
${ }^{1}$ 東京都健康長寿医療センター研究所神経画像研究チーム \\ 2 東京都健康長寿医療センター放射線診断科 \\ ${ }^{3}$ 国際医療福祉大学保健医療学部 \\ ${ }^{4}$ 北海道科学大学保健医療学部 \\ ${ }^{5}$ 現 Molecular Imaging and Therapy Service, Memorial Sloan Kettering Cancer Center
}

\section{緒 言}

${ }^{18}$ F-fluoro-2-deoxy-D-glucose $\left({ }^{18} \mathrm{~F}-\mathrm{F}\right.$ DG) を用いた positron emission tomography (PET) 検査は悪性腫瘍 のスクリーニング, 病期診断, 転移・再発診断に有用 とされている. 近年では, ${ }^{18} \mathrm{~F}-\mathrm{FDG}$ やその他のト
レーサーから得られる病変の機能情報を加味した放射 線治療計画の実施など，利用の幅を広げている2)。し かし, PETは撮像に数分要するため, 肺や上腹部臟器 の腫瘍は呼吸の影響を受け，ボケの発生，定量值の過 小評価，腫瘍の位置の誤認，減弱補正用 computed to-

\title{
Evaluation of a New Motion-correction Algorithm Using On-rigid Registration in Respiratory-gated PET/CT Images of Liver Tumors
}

Kei Wagatsuma, ${ }^{1 *}$ Tatsufumi Osawa, ${ }^{2}$ Naoki Yokokawa, ${ }^{2}$ Kenta Miwa, ${ }^{3}$ Keiichi Oda, ${ }^{1,4}$ Yoshiro Kudo, ${ }^{2}$ Yasushi Unno, ${ }^{2}$ Kimiteru Ito, ${ }^{2,5}$ and Kenji Ishii ${ }^{1}$

${ }^{1}$ Research Team for Neuroimaging, Tokyo Metropolitan Institute of Gerontology

${ }^{2}$ Department of Radiology, Tokyo Metropolitan Geriatric Hospital

${ }^{3}$ School of Health Science, International University of Health and Welfare

${ }^{4}$ Faculty of Health Science, Hokkaido University of Science

${ }^{5}$ Current address: Molecular Imaging and Therapy Service, Memorial Sloan Kettering Cancer Center

Received August 24, 2016; Revision accepted September 19, 2016

Code No. 333

\section{Summary}

Objective: The present study aimed to determine the qualitative and quantitative accuracy of the Q.Freeze algorithm in PET/CT images of liver tumors. Methods: A body phantom and hot spheres representing liver tumors contained 5.3 and $21.2 \mathrm{kBq} / \mathrm{mL}$ of a solution containing ${ }^{18} \mathrm{~F}$ radioactivity, respectively. The phantoms were moved in the superior-inferior direction at a motion displacement of $20 \mathrm{~mm}$. Conventional respiratory-gated (RG) and Q.Freeze images were sorted into 6,10, and 13 phase-groups. The $\mathrm{SUV}_{\text {ave }}$ was calculated from the background of the body phantom, and the $\mathrm{SUV}_{\max }$ was determined from the hot spheres of the liver tumors. Three patients with four liver tumors were also clinically assessed by whole-body and RG PET. The RG and Q.Freeze images derived from the clinical study were also sorted into 6,10 and 13 phase-groups. Liver signal-to-noise ratio (SNR) and $\mathrm{SUV}_{\max }$ were determined from the RG and Q.Freeze clinical images. Results: The $\mathrm{SUV}_{\text {ave }}$ of Q.Freeze images was the same as those derived from the body phantom using RG. The liver SNR improved with Q.Freeze, and the SUVs max $_{\max }$ was not overestimated when Q.Freeze was applied in both the phantom and clinical studies. Q.Freeze did not degrade the liver SNR and $\mathrm{SUV}_{\max }$ even though the phase number was larger. Conclusions: Q.Freeze delivered qualitative and quantitative motion correction than conventional RG imaging even in 10-phase groups.

Key words: ${ }^{18} \mathrm{~F}-\mathrm{FDG}$, positron emission tomography (PET), respiratory gating, non-rigid registration, liver tumor

*Proceeding author 
mography (CT) 画像とのズレによる減弱補正エラーな どの問題が発生する ${ }^{3.4)}$. 肺癌において呼吸性移動の 影響は下肺野かつ胸壁などで固定されていない腫瘍で 顕著である の呼吸性移動による平均移動距離は $9.0 \pm 5.0 \mathrm{~mm}$ と報 告されている6).

PET の呼吸制御法は多くの研究が報告されており, 深吸気息止め PET 撮像 ${ }^{7.8)}$ ，呼吸同期 PET 撮像 ${ }^{9}$ 10) な どがある。呼吸同期 PET 撮像は外部デバイスより取 得した被検者の呼吸波形の位相を任意の位相分割数で 分割し，同じ位相のデー夕を加算して画像を作成する 手法である. Nehmeh らは呼吸同期 PET 撮像により 肺癌の体積計測と定量值が改善したと報告した9 Suenaga らは肝転移の被検者に呼吸同期 PET 撮像を 施行した結果, 非呼吸同期撮像と比べて肝転移の検出 能が向上したと報告している ${ }^{11}$ 。 しかし，呼吸同期 PET 撮像は十分な撮像時間が必要であり, 全体の PET 検査時間が延長するという問題点がある ${ }^{12}$. 呼 吸同期 PETでは，限られた時間内で収集した全体の PETデータを任意の呼吸相に分割するため，1位相あ たりに入るデータが位相分割数で除した量に減少し, 結果的に統計雑音が増加する。Park らは10 分間の撮 像時間に扔いて呼吸同期 PET 撮像の位相分割数が 5 より大きくなると, 統計雑音の増加にともない signalto-noise ratio (SNR) の低下や定量值を過大評価すると 報告している

呼吸同期 PET 撮像の統計雑音の増加による SNR の低下を解決する方法として, Q.Freeze (GE Healthcare 社)が提案された ${ }^{13,14)}$. Q.Freeze は非線形 レジストレーション処理である optical flow based registration 技術を応用している。呼吸同期 PET 撮 像で得られたすべての位相の各ボクセルの動きを，組 織の粘性 (viscosity) や弾性 (elasticity) 考慮して識別 し，基準とした任意の位相のボクセルへ合わせ込み PET 画像を作成する。つまり，呼吸同期 PET 撮像の 任意の位相の PET 画像に他のすべての位相の PET 画像を合わせ込むことが可能になる。最終的な PET 画像のボクセル内に入るカウント值は, すべての位相 のカウント值から statistical median algorithm を用い て中央值を抽出している ${ }^{13)}$. 最近, Minamimoto らが 臨床例を用いてQ.Freezeによる画質改善効果と短時 間収集の可能性について評価し, Q.Freezeの有用性 を初めて報告した，Q.FreezeによるPET 画像は非呼 吸同期画像, 呼吸同期画像と比較して画質が優れてお り, Q.Freeze は従来の呼吸同期撮像よりも撮像時間 を短縮可能であると報告した ${ }^{14)}$. しかし, 当該臨床研
究は, 腫瘍の性状 (サイズ, 放射能濃度, 移動量) が異 なる症例を混合してQ.Freezeの効果を評価してい る. 更に, 臨床で採用している 1 種類の呼吸同期 PET 撮像条件のみで検討しており，特にQ.Freezeの 効果に最も影響を与えると考えられる位相分割数によ る影響について評価していない，以上のことから，

Q.Freezeによる画質, 定量性に対する基本的な効果 を十分に評価できているとは言い難い，そこで本研究 は, 肝臓腫瘍を模擬したファントムと肝臓腫瘍の臨床 例を対象として, 呼吸同期 PET 画像の位相分割数を 変化させた際の, Q.Freezeによる画質と定量性への 効果を検証し, Q.Freezeの有用性を評価した。

\section{1. 方 法}

\section{1-1 使用機器 $\cdot$ 器具 \\ 1-1-1 PET/CT 装置}

$\mathrm{PET} / \mathrm{CT}$ 装置は Discovery $\mathrm{PET} / \mathrm{CT} 710$ (GE Healthcare 社)を用いた ${ }^{15)}$. PETの体軸方向視野は $157 \mathrm{~mm}$, 断面方向視野は $700 \mathrm{~mm}$ である. CT の断 面方向視野は $500 \mathrm{~mm}$ である. CT 部分は 64 列の CT である.PETの検出器は lutetium-yttriumorthosilicate シンチレータであり, 結晶素子の大きさ は 4.2×6.3×25 mm である. 画像再構成条件は 3 dimensional-ordered-subsets-expectation-maximization, マトリクスサイズ $192 \times 192$, 繰り返し数 2, サブセッ ト 18, ガウシアンフィルタ $4.0 \mathrm{~mm}, \mathrm{Z}$-axis filter は Light, time-of-flight 補正および point-spread-function (PSF) 補正は両方とも使用した，スライス数は 1 ベッ ドあたり 47 スライス，スライス厚は $3.27 \mathrm{~mm}$ ，ピク セルサイズは $2.6 \mathrm{~mm}$ である.

\section{1-1-2ファントム}

National Electrical Manufactures Association (NEMA) International Electrotechnical Commission (IEC) 胴体ファントム (Data Spectrum 社) は人の胴体 を模擬した形状であり, 長径 $30 \mathrm{~cm}$, 短径 $23 \mathrm{~cm}$, 奥 行き $18 \mathrm{~cm}$ である. 内部に六つのアクリル球が設置 されており，内径はそれぞれ $37,28,22,17,13,10$ mm である (Fig. 1a).

肝臓模擬ファントムとして, 長径 $19 \mathrm{~cm}$, 短径 12 $\mathrm{cm}$, 深さ $6 \mathrm{~cm}$ のプラスチック容器を用いた。 プラス チック容器に溶かした寒天を入れ, 冷蔵庫で一昼夜冷 やして固めた，寒天の内部に内径 $10,20 \mathrm{~mm}$ のアク リル球を設置した(Fig. 1b).

\section{1-1-3 呼吸同期プラットフォーム}

呼吸同期プラットフォームは自作のものを使用し た。 パーソナルコンピュータで作成した入力波形に応 


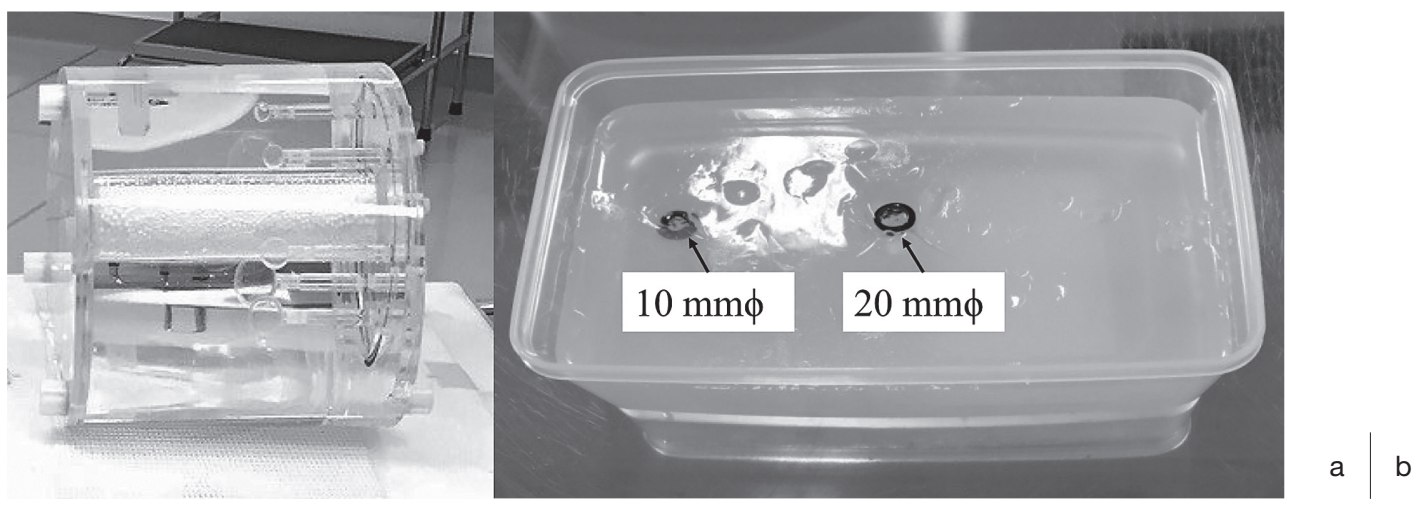

Fig. 1 (a) NEMA IEC body phantom

(b) Phantom-simulated liver tumor. The two acrylic hot spheres, 10 and $20 \mathrm{~mm}$ in diameter, in an agar gel phantom.

Table 1 List of subjects

\begin{tabular}{|c|c|c|c|c|c|c|c|c|c|}
\hline $\begin{array}{l}\text { Subject } \\
\text { number }\end{array}$ & $\begin{array}{l}\text { Age } \\
(\mathrm{y})\end{array}$ & Sex & $\begin{array}{l}\text { Height } \\
(\mathrm{cm})\end{array}$ & $\begin{array}{c}\text { Weight } \\
(\mathrm{kg})\end{array}$ & $\begin{array}{l}\text { Body Mass } \\
\text { Index }\end{array}$ & $\begin{array}{l}\text { Injected dose } \\
(\mathrm{MBq})\end{array}$ & $\begin{array}{l}\text { Uptake time } \\
\text { (min) }\end{array}$ & Primary tumor & $\begin{array}{l}\text { Diameter of liver } \\
\text { metastases }(\mathrm{mm})\end{array}$ \\
\hline $1-1$ & \multirow[b]{2}{*}{80} & \multirow[b]{2}{*}{ Male } & \multirow[b]{2}{*}{168} & \multirow[b]{2}{*}{60.0} & \multirow[b]{2}{*}{21.3} & \multirow[b]{2}{*}{201.0} & \multirow[b]{2}{*}{60} & \multirow[b]{2}{*}{ Rectum } & 4.0 \\
\hline $1-2$ & & & & & & & & & 40.0 \\
\hline 2 & 88 & Female & 139 & 36.2 & 18.7 & 183.0 & 59 & Cervical & 6.0 \\
\hline 3 & 78 & Female & 148 & 46.9 & 21.4 & 185.0 & 60 & $\begin{array}{c}\text { Stomach, } \\
\text { Breast }\end{array}$ & 12.0 \\
\hline
\end{tabular}

じてモータが作動する。モータによりアクリル板が上 下方向に反復運動し，アクリル板の動きと連動して ファントムを載せたプレートが頭尾方向にスライドす

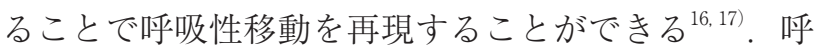
吸モニタリングシステムは Varian real-time position management respiratory gating system (RPM システ ム, Varian Medical Systems 社)を用いた. RPM シス テムの動作確認用の BREATHING PHANTOM GATING ASSY (Varian Medical Systems 社)の波形信 号を入力波形として取り出し, 呼吸同期プラット フォーム付属のパーソナルコンピュータに入力した。 呼吸同期プラットフォームのアクリル板の上に反射 マーカを載せ, 赤外線カメラによって呼吸波形を取得 した。

\section{1-2 ファントム撮像}

胴体ファントムのバックグラウンドに放射能濃度が $5.3 \mathrm{kBq} / \mathrm{mL}$ になるように ${ }^{18} \mathrm{~F}-\mathrm{FDG}$ 溶液を調製した。 肝臓模擬ファントムの 10, $20 \mathrm{~mm}$ のアクリル球には 放射能濃度が $21.2 \mathrm{kBq} / \mathrm{mL}$ になるように調製した ${ }^{18} \mathrm{~F}-\mathrm{FDG}$ 溶液を封入した。作製した 2 種類のファント ムはそれぞれ PET/CT 装置の寝台の上に載せた呼吸 同期プラットフォームのプレート上に置いた。呼吸同 期プラットフォームを動かしていない状態で静止撮像 を行った。呼吸同期プラットフォームを動かした状態
で呼吸同期撮像を行った。呼吸同期プラットフォーム の変位量は臨床における肝臓腫瘍の平均移動距離を十 分に満足する $20 \mathrm{~mm}$ とした。静止撮像および呼吸同 期撮像は臨床時の収集時間と同様にし，静止撮像は 2.5 分間，呼吸同期撮像は 6 分間収集した。取得した 波形の 1 周期を 6, 10，13 相に分割して呼吸同期画像 をそれぞれ作成した。その後, PET/CT 装置のコン ソール上で呼吸同期撮像の $6,10,13$ 相の各位相ひと つひとつを基準としたQ.Freeze 画像を作成した。

\section{1-3 臨床撮像}

本検討は当施設の倫理委員会の承認を得て実施した (No. 260409). 2013 年 6 月から 2014 年 11 月までの 間, ${ }^{18} \mathrm{~F}-\mathrm{FDG}$ PET/CT 全身撮像と呼吸同期撮像を施行 した被検者のうち, 肝臓に転移があった 3 症例 4 病変 を対象とした。被検者リストをTable 1 にまとめた。 収集時間はファントム実験と同様に全身撮像は非同期 撮像で 1 ベッドを 2.5 分間, 呼吸同期撮像は 6 分間と した。ファントム実験と同じく, PET/CT 装置のコ ンソール上で呼吸同期撮像の $6,10,13$ 相の各位相ひ とつひとつを基準としたQ.Freeze 画像を作成した.

\section{1-4 ファントム評価}

画像の均一性は, 胴体ファントムのアクリル球が明 瞭に描出されているスライスのバックグラウンド部に 
直径 $37 \mathrm{~mm}$ の円形の関心領域 (region of interest: ROI）を 12 個設定した. ROI の mean standardized uptake value $\left(\mathrm{SUV}_{\text {mean }}\right)$ を計測したのちに, 12 個の $\mathrm{SUV}_{\text {mean }}$ の平均值である average $\mathrm{SUV}\left(\mathrm{SUV}_{\mathrm{ave}}\right)$ を算出 した ${ }^{18)}$. 定量值は, CT 画像を参照して肝臓模擬ファ ントムのアクリル球が明瞭に描出されているスライス にアクリル球の $10,20 \mathrm{~mm}$ の内径と等しい円形 ROI をアクリル球に設定し， SUV $\mathrm{S}_{\text {max }}$ を測定した. $\mathrm{SUV}_{\mathrm{ave}}$, $\mathrm{SUV}_{\max }$ は静止撮像, 呼吸同期撮像, Q.Freeze から算 出した。呼吸同期撮像, Q.Freeze においては 6, 10, 13 相の画像のすべての位相の $\mathrm{SUV}_{\mathrm{ave}}, \mathrm{SUV}_{\max }$ の平均 值と標準偏差 (standard deviation: SD) を算出した.

\section{$1-5$ 臨床評価}

臨床画像の画質の確認として, PET の coronal 画像 で被検者の正常肝茞部に直径 $30 \mathrm{~mm}$ の円形 ROI を三 つ，3 スライス連続に合計九つ設定した。すべての ROI の PET 放射能濃度 $\mathrm{kBq} / \mathrm{mL}$ の平均值と標準偏差 を算出し, 以下の式で肝蔵 SNR を算出した ${ }^{18)}$ 。定量 值は内径 $20 \mathrm{~mm}$ の球形の volume of interestを用い

Table 2 Average standardized uptake value in the background of phantom

\begin{tabular}{cccc}
\hline \hline \multirow{2}{*}{ Gated methods } & \multicolumn{3}{c}{ Number of phases } \\
\cline { 2 - 4 } & 6 & 10 & 13 \\
\hline RG & 1.01 & 1.01 & 1.08 \\
QF & 1.00 & 1.01 & 1.08 \\
\hline
\end{tabular}

$\mathrm{SUV}_{\text {ave }}=1.03$ for stationary imaging of phantom

RG: respiratory-gated PET; QF: Q. Freeze
て 4 病変の $\mathrm{SUV}_{\max }$ を抽出した. 肝臓 SNR, SUV max は全身撮像, 呼吸同期撮像, Q.Freeze から算出した。 呼吸同期撮像と Q.Freeze においては 6, 10，13 相の 画像のすべての位相の肝臓 $\operatorname{SNR}\left(\right.$ 式 1), $\mathrm{SUV}_{\max }$ の平 均值と標準偏差を算出した。

Liver $\mathrm{SNR}=\frac{\mathrm{C}_{\text {liver }}}{\mathrm{SD}_{\text {liver }}}$

このとき, $\mathrm{C}_{\text {liver }}$ は肝臓部の 3 スライス描画した ROI 值の平均值, $\mathrm{SD}_{\text {liver }}$ は肝臓部の 3 スライス描画した ROI 值の標準偏差の平均值とした。

\section{2. 結 果}

\section{2-1 ファントム評価}

胴体ファントムのバッググラウンドの $\mathrm{SUV}_{\mathrm{ave}}$ の結 果をTable 2 に示す。呼吸同期撮像, Q.Freeze 間に $\mathrm{SUV}_{\mathrm{ave}}$ の違いはなかったが, 13 相で若干の増加傾向 を示した。肝蔵模擬ファントムの $\mathrm{SUV}_{\max }$ を Fig. 2 に 示す。静止撮像時の $10,20 \mathrm{~mm}$ 球の $\mathrm{SUV}_{\text {max }}$ はそれぞ れ 20.3，21.0であった. $10 \mathrm{~mm}$ 球の呼吸同期撮像と Q.Freeze の $\mathrm{SUV}_{\max }$ の平均值土標準偏差は 18.3 \pm 3.8 ,

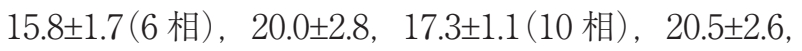
$17.8 \pm 0.8$ (13 相)であった. $20 \mathrm{~mm}$ 球の呼吸同期撮像と Q.Freeze の $\mathrm{SUV}_{\text {max }}$ の平均值土標準偏差は 21.7 \pm 3.0 ,

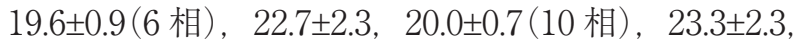
$20.2 \pm 0.5$ (13 相)であった. Q.Freeze は呼吸同期画像と 比べて平均值と標準偏差ともに低い值を示した. 位相 分割数が 6 相のときの $\mathrm{SUV}_{\text {max }}$ を基準として, $10 \mathrm{~mm}$ 球の呼吸同期撮像と Q.Freeze の $\mathrm{SUV}_{\max }$ の増加率は 9.3， 14.1\% (10 相)， 12.0， 12.7\% (13 相)であった. 20

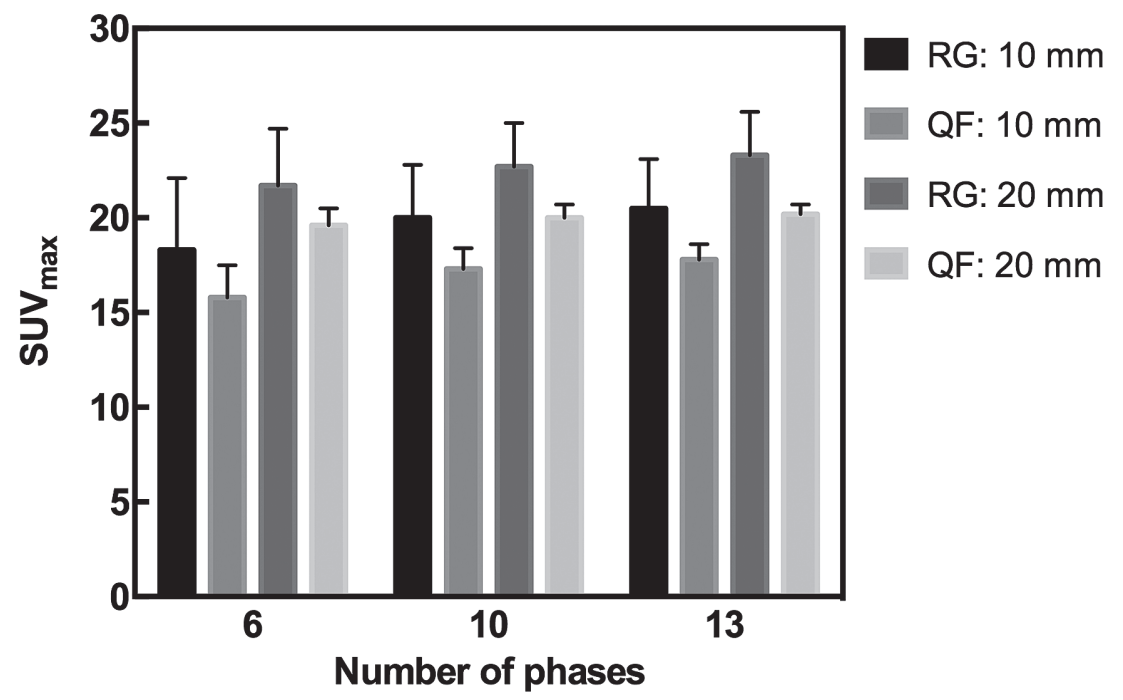

Fig. 2 Maximum standardized uptake value $\left(\mathrm{SUV}_{\max }\right)$ of the phantom-simulated liver tumor with respiratory-gated PET and Q.Freeze.

The SUV $V_{\max }$ with Q.Freeze was smaller than the respiratory-gated PET and was not changed in larger phase number. RG: respiratory-gated PET; QF: Q.Freeze 
A

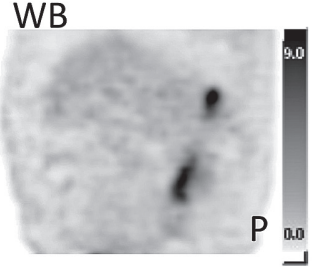

RG: 6 phase

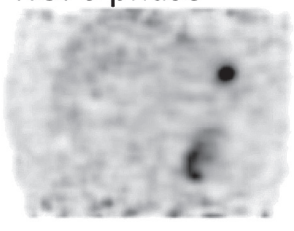

QF: 6 phase

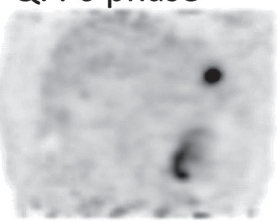

RG: 10 phase

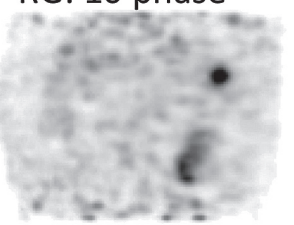

QF: 10 phase

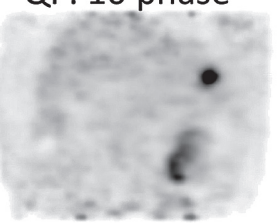

RG: 13 phase

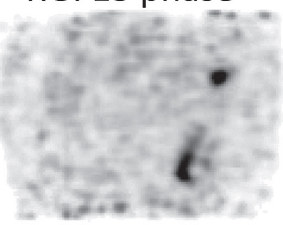

QF: 13 phase

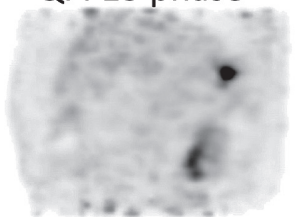

Fig. 3 Representative sagittal PET images of whole body PET, respiratory-gated PET and Q.Freeze. Respiratory-gated PET and Q.Freeze improved image blurring of liver tumor due to respiratory motion. Q.Freeze reduced the statistical noise in the liver. WB: whole body; RG: respiratory-gated PET; QF: Q.Freeze; A: anterior; P: posterior

$\mathrm{mm}$ 球の呼吸同期撮像と Q.Freeze の $\mathrm{SUV}_{\text {max }}$ の増加 率は 4.6, 2.0\% (10 相)，7.4，3.1\% (13 相)であった。呼 吸同期画像, Q.Freeze ともに位相分割数の増加につ れて $\mathrm{SUV}_{\max }$ も増加した。

\section{2-2 臨床評価}

全身撮像の肝臓部分と, 呼吸同期撮像, Q.Freeze の 最大呼気時の症例 (被検者 3 番) を Fig. 3 に示す。臨 床画像において，全身撮像は動きの影響を受けて腫瘍 の尾側にボケを認めた。一方，呼吸同期画像と Q.Freeze は全身撮像で認めたボケが改善した。呼吸 同期画像では肝臓に統計雑音が認められたが, Q.Freeze では統計雑音が抑制されていた。しかし， 位相分割数 13 相では 6,10 相と比較して腫瘍の集積 が歪んでいた。

全症例の肝臓 SNR の平均值を Table 3 に示す。全 身撮像時の肝臓 SNR より呼吸同期撮像と Q.Freeze は低值を示した。. Q.Freeze は呼吸同期撮像よりも改 善した。呼吸同期撮像，Q.Freeze ともに位相分割数 が増えるほど肝臓 SNR は低下傾向を示した。各肝臓 病変の全身撮像，呼吸同期撮像，Q.Freeze の $\mathrm{SUV}_{\text {max }}$ と全症例の平均 $\mathrm{SUV}_{\text {max }}$ をそれぞれ Table 4 に示す。 肝臟腫瘍の $\mathrm{SUV}_{\text {max }}$ は呼吸同期撮像, Q.Freeze, 全身 撮像の順で高值を示した。. Q.Freeze は位相分割数が 増えても $\mathrm{SUV}_{\text {max }}$ に変化はなく, 標準偏差も小さかった.

\section{3. 考 察}

本研究では肝臓腫瘍を模擬したファントムと肝転移 に対して呼吸同期撮像を行い，位相分割数を变化させ た時の画像の均一性および定量性における Q.Freeze の有用性について検討した。.Freeze は任意の数に
Table 3 Average liver signal-to-noise ratios

\begin{tabular}{cccc}
\hline \multirow{2}{*}{ Gated methods } & \multicolumn{3}{c}{ Number of phases } \\
\cline { 2 - 4 } & 6 & 10 & 13 \\
\hline RG & $4.6 \pm 0.9$ & $3.7 \pm 0.9$ & $3.4 \pm 0.8$ \\
QF & $7.7 \pm 0.4$ & $7.2 \pm 0.3$ & $7.0 \pm 0.6$ \\
\hline
\end{tabular}

9.4 for liver signal to noise ratio in static imaging RG: respiratory-gated PET; QF: Q. Freeze

位相分割した呼吸同期 PET 画像のある位相の画像を 基準とし，その他の位相の画像を非線形レジストレー ション処理で合わせ込み PET 画像を作成する ${ }^{13)}$. 本 研究ではQ.Freeze をすべての位相において行い，呼 吸性移動を描出できる Q.Freeze 画像を作成した。 Q.Freeze は呼吸同期撮像よりも均一性は改善し, 定 量值は統計雑音が抑えられ低值を示した。 Q.Freeze は撮像時間 6 分間において位相分割数が 10 相と高い 時間分解能であっても画質と定量值が安定しているこ とが明らかになった。

画像の均一性はファントムのバックグラウンドと臨 床画像の肝臟 SNR から評価した。ファントムのバッ クグラウンドは位相分割数 13 相以外で呼吸同期撮像, Q.Freeze ともにがん FDG PET/CT 撮像法ガイドラ インのバックグラウンドの確認の $\mathrm{SUV}_{\mathrm{ave}}=1.00 \pm 0.05$ を ほぼ満たしており，均一性は担保されていた ${ }^{18)}$ 。胴体 ファントムのようにバックグラウンドが均一な ${ }^{18} \mathrm{~F}$ FDG 溶液で満たされている場合，本研究で使用した 二次元の規則的な移動では影響が少なかったと考え る。また，呼吸同期撮像によって 1 位相あたりのカウ ントデータが減少して ROI 内の統計雑音が増加した としても， $\mathrm{SUV}_{\text {ave }}$ は ROI 内の平均值を計測している ために安定していたと考える。一方，臨床画像の肝臓 
Table 4 Maximum standardized uptake value of liver lesion in each subject

\begin{tabular}{|c|c|c|c|c|c|c|c|}
\hline \multirow{2}{*}{$\begin{array}{l}\text { Subject } \\
\text { number }\end{array}$} & \multirow{2}{*}{$\mathrm{SUV}_{\max } \mathrm{WB}$} & \multicolumn{3}{|c|}{$\mathrm{SUV}_{\max \_} \mathrm{RG}$} & \multicolumn{3}{|c|}{$\mathrm{SUV}_{\text {max__}} \mathrm{QF}$} \\
\hline & & 6 & 10 & 13 & 6 & 10 & 13 \\
\hline $1-1$ & 3.0 & $4.0 \pm 0.5$ & $4.0 \pm 0.4$ & $4.2 \pm 0.5$ & $3.3 \pm 0.1$ & $3.3 \pm 0.1$ & $3.3 \pm 0.2$ \\
\hline $1-2$ & 25.9 & $27.8 \pm 3.8$ & $27.9 \pm 3.0$ & $28.8 \pm 3.2$ & $24.1 \pm 1.6$ & $23.8 \pm 1.1$ & $24.1 \pm 1.0$ \\
\hline 2 & 9.0 & $11.3 \pm 1.0$ & $11.7 \pm 0.9$ & $12.7 \pm 1.6$ & $9.5 \pm 0.3$ & $9.5 \pm 0.5$ & $9.4 \pm 0.2$ \\
\hline 3 & 9.2 & $15.2 \pm 1.9$ & $15.4 \pm 2.6$ & $15.7 \pm 2.8$ & $12.8 \pm 0.9$ & $12.8 \pm 1.0$ & $12.6 \pm 0.8$ \\
\hline
\end{tabular}

$\mathrm{SUV}_{\max }$ : maximum standardized uptake value; WB: whole body; RG: respiratory-gated PET; QF: Q. Freeze

SNR では, Q.Freeze は各ボクセルに対して呼吸同期 画像のすべての位相のカウント值から statistical median algorithm を用いて中央値を抽出して, 最終画像 のボクセル值としている。結果的に統計雑音は抑制さ れ，呼吸同期撮像よりも肝臟 SNR が改善した ${ }^{13)}$. 位 相分割数の増加に応じて肝臟 SNR は低下傾向を示し たが，Q.Freeze は呼吸同期撮像よりも位相分割数の 増加による肝臓 SNRの低下は緩徐であった。 Minamimoto らは収集時間 3, 5, 10 分と変化させた位 相分割数 5 相の Q. Freeze 画像を作成した ${ }^{14}$. Q.Freeze により肝臓 SNR は呼吸同期撮像よりも改善 したが，位相分割数あたりの収集カウントが少ないほ ど肝臓の SNR は低下傾向を示した。これは本研究と 同様の傾向を示した，位相分割数が大きすぎると，元 の呼吸同期撮像の位相分割数あたりの収集カウントが 極端に少なく信頼性が低下するため, Q.Freeze で中 央値を抽出したとしても肝臟 SNR は低下したと考え られる。

定量性は肝臓腫瘍を模擬したファントムの $\mathrm{SUV}_{\max }$ と臨床画像の肝臓腫瘍の $\mathrm{SUV}_{\max }$ を評価した。ファン トムと臨床画像ともにQ.Freeze の SUV max $_{\text {m }}$ は呼吸同 期撮像よりも低值を示した，中央值を利用する Q.Freeze は位相分割による統計雑音の増加に起因す る外れ值の影響を受けず $\mathrm{SUV}_{\text {max }}$ の過大評価を抑制す ることが可能と考える ${ }^{4,13,14)}$. 肝臟模擬ファントムの 実験より Q.Freeze の $10 \mathrm{~mm}$ 球の $\mathrm{SUV}_{\text {max }}$ は静止撮像 時の $\mathrm{SUV}_{\text {max }}$ の 20.3 より約 8 割程度過小評価された。

Teoらや三輪らは呼吸性移動が腫瘍サイズより大き いとき呼吸性移動と部分容積効果の両者の影響を受 け，呼吸同期撮像による定量值の改善効果は低いと報 告しており ${ }^{12.17)}$ ，Q.Freeze を利用したとしても改善効 果は見込めなかった。中村らは，バックグラウンドと ホット球の放射能濃度比が大きいほど PSF 補正によ る Gibbs アーチファクトの定量值の過大評価の影響は 大きいと報告している ${ }^{19)}$ ，今回の検討では，肝臟模擬 腫瘍のバックグラウンドはコールドとしたために Gibbs アーチファクトによる過大評価が大きく, 10 $m m$ 球の部分容積効果と競合した結果，過小評価が 8 割程度に留まったと考える。本研究より, 呼吸同期撮 像に対する Q.Freeze の SUV max $_{\text {max }}$ はフントム実験と 臨床例で同じ傾向を示したことから, Minamimotoら の報告の裏付けとなったと考える.

ファントムおよび臨床評価では, 呼吸同期撮像では 位相分割数の増加にともない $\mathrm{SUV}_{\text {max }}$ は増加したが, Q.Freeze は変化しなかった. Park らは NEMA IEC 胴体ファントムを用いて, 呼吸同期 PET 撮像の位相 分割数を変化させた．位相分割数が 10 相以上だと定 量值を過大評価し, 画質も劣化すると報告し, 病変検 出に関わる時間分解能と画質を両立する位相分割数は 5 相と報告した4). 同様に, Mancosu らは呼吸同期 PET 撮像による病変の移動の改善と統計雑音を両立 させる最適な位相分割数は 6 相と報告した20). Suenaga らは肝転移に呼吸同期 PET 撮像を実施する ことで, 放射線治療計画の正確な照射体積の設定だけ でなく, 正確な定量值の測定により, 治療効果判定や 予後予測にも貢献する可能性があると報告している。 しかし，上記の報告は通常の呼吸同期 PET 撮像であ り，な扔かつ位相分割数が 4 相であった ${ }^{11)}$ 。放射線治 療計画用の呼吸同期 CT の位相分割数は 10 相を用い た報告が多い21 23)。われわれの結果より, Q.Freezeは 位相分割数 10 相ならば画質, 定量性ともに担保され ていた。本研究のように各位相で Q.Freeze 画像を作 成することで, 従来トレードオフの関係であった呼吸 性移動の描出と正確な定量值の測定が両立でき, 腫瘍 の生物学的情報をより反映した放射線治療計画の立案 や治療効果判定, 予後予測への利用が可能となると考 える，

本研究では肝臓模擬ファントムとして寒天を満たし たプラスチック容器にアクリル球を埋め込んで作成し た。人体を詳細に模擬したファントムの作製には胴体 ファントムなどに ${ }^{18} \mathrm{~F}-\mathrm{FDG}$ 溶液と寒天を混ぜてバッ クグラウンドを作製する必要がある。また，本研究の 臨床評価では症例数が 4 病変と少なかった。肝転移の 治療戦略に PET/CT 検査が貢献するには従来の呼吸 
同期 PET 撮像では検出困難だとされている微小 $(7$ $\mathrm{mm}$ 以下)の肝転移を検出することが重要である ${ }^{24)}$.

また，放射線治療への広い利用を考えるうえでは，よ り呼吸性移動の大きい肺癌での検討も必要であると考 える. 今後, 症例数を増やしてQ.Freeze の有用性に 関する更なる検討を行う必要がある。

\section{4. 結 語}

非線形レジストレーション処理である Q.Freeze は
従来の呼吸同期 $\mathrm{PET} / \mathrm{CT}$ 撮像の問題であった統計雑 音の増加による画質や定量值の精度低下を改善でき た. Q.Freeze は位相分割数が 10 相でも画質および定 量值に大きな変化はなく, 肝臓腫瘍の呼吸性移動によ る影響を軽減した。よって, 従来の呼吸同期 PET/ $\mathrm{CT}$ 撮像よりも短時間で肝臓腫瘍の描出と定量值の測 定を高い精度で行うことが可能であり，放射線治療計 画での利用が期待される.

\section{参考文献}

1) Sahiner I, Vural GU. Positron emission tomography/computerized tomography in lung cancer. Quant Imaging Med Surg 2014; 4(3): 195-206.

2) Aristophanous M, Berbeco RI, Killoran JH, et al. Clinical utility of 4D FDG-PET/CT scans in radiation treatment planning. Int J Radiat Oncol Biol Phys 2012; 82(1): e99-105.

3) Callahan J, Binns D, Dunn L, et al. Motion effects on SUV and lesion volume in 3D and 4D PET scanning. Australas Phys Eng Sci Med 2011; 34(4): 489-495.

4) Park SJ, Ionascu D, Killoran J, et al. Evaluation of the combined effects of target size, respiratory motion and background activity on 3D and 4D PET/CT images. Phys Med Biol 2008; 53(13): 3661-3679.

5) Shirato H, Seppenwoolde $Y$, Kitamura K, et al. Intrafractional tumor motion: lung and liver. Semin Radiat Oncol 2004; 14(1): 10-18.

6) Kitamura K, Shirato H, Seppenwoolde Y, et al. Tumor location, cirrhosis, and surgical history contribute to tumor movement in the liver, as measured during stereotactic irradiation using a real-time tumor-tracking radiotherapy system. Int $\mathrm{J}$ Radiat Oncol Biol Phys 2003; 56(1): 221-228.

7) Nehmeh SA, Erdi YE, Meirelles GS, et al. Deep-inspiration breath-hold PET/CT of the thorax. J Nucl Med 2007; 48(1): 2226.

8) Meirelles GS, Erdi YE, Nehmeh SA, et al. Deep-inspiration breath-hold PET/CT: clinical findings with a new technique for detection and characterization of thoracic lesions. J Nucl Med 2007; 48(5): 712-719.

9) Nehmeh SA, Erdi YE, Ling CC, et al. Effect of respiratory gating on quantifying PET images of lung cancer. J Nucl Med 2002; 43(7): 876-881.

10) Nehmeh SA, Erdi YE, Ling CC, et al. Effect of respiratory gating on reducing lung motion artifacts in PET imaging of lung cancer. Med Phys 2002; 29(3): 366-371.

11) Suenaga $Y$, Kitajima $K$, Aoki $H$, et al. Respiratory-gated ${ }^{18} \mathrm{~F}$ FDG PET/CT for the diagnosis of liver metastasis. Eur J Radiol 2013; 82(10): 1696-1701.

12) Teo BK, Saboury B, Munbodh R, et al. The effect of breathing irregularities on quantitative accuracy of respiratory gated PET/CT. Med Phys 2012; 39(12): 7390-7397.

13) Ganin A. Q.Freeze. http://www3.gehealthcare.co.uk/ /media/ downloads/uk/education/pet $\% 20$ white $\% 20$ papers/qfreezewhi-
tepaperdoc1232441201211.pdf?Parent=\% 7BB66C9E27-1C454F6B-BE27-D2351D449B19\%7D (Accessed 2016.7.27).

14) Minamimoto R, Mitsumoto $T$, Miyata $Y$, et al. Evaluation of a new motion correction algorithm in PET/CT: combining the entire acquired PET data to create a single three-dimensional motion-corrected PET/CT image. Nucl Med Commun 2016; 37 (2): 162-170.

15) Bettinardi V, Presotto L, Rapisarda E, et al. Physical performance of the new hybrid PET/CT Discovery-690. Med Phys 2011; 38(10): 5394-5411.

16) Tachibana $H$, Kitamura $N$, Ito $Y$, et al. Management of the baseline shift using a new and simple method for respiratorygated radiation therapy: detectability and effectiveness of a flexible monitoring system. Med Phys 2011; 38(7): 3971-3980.

17）三輪建太, 我妻 慧, 梅田拓朗, 他. 位相呼吸同期 PET/ CT 撮像による PET 定量值の改善率の検討. 日放技学誌 2014; 70(11): 1235-1242.

18）福喜多博義, 織田圭一, 白石貴博, 他. がん FDG PET/CT 撮像法ガイドライン第 2 版。核医学技術 2013; 33(4): 377-420.

19）中村明弘, 谷崎靖夫, 竹内美穂, 他. PET 画像における PSF 補正が定量值に与える影響一ファントム実験と臨床 画像からの検討一. 日放技学誌 2014; 70(6): 542-548.

20) Mancosu P, Sghedoni R, Bettinardi V, et al. 4D-PET data sorting into different number of phases: a NEMA IQ phantom study. J Appl Clin Med Phys 2009; 10(4): 220-231.

21) Matoba $M$, Oota $K$, Toyoda I, et al. Usefulness of $4 D-C T$ for radiation treatment planning of gastric MZBCL/MALT. J Radiat Res 2012; 53(2): 333-337.

22) Chan MK, Kwong DL, Ng SC, et al. Experimental evaluations of the accuracy of $3 \mathrm{D}$ and $4 \mathrm{D}$ planning in robotic tracking stereotactic body radiotherapy for lung cancers. Med Phys 2013; 40(4): 041712.

23) Heinzerling JH, Bland R, Mansour JC, et al. Dosimetric and motion analysis of margin-intensive therapy by stereotactic ablative radiotherapy for resectable pancreatic cancer. Radiat Oncol 2011; 6: 146.

24) Hassler S, Hubele F, Constantinesco A, et al. Comparing respiratory gated with delayed scans in the detection of colorectal carcinoma hepatic and pulmonary metastases with ${ }^{18}$ F-FDG PET-CT. Clin Nucl Med 2014; 39(1): e7-e13. 